\title{
The Role of Sphingolipids in Allergic Disorders
}

\section{Araceli Díaz-Perales ${ }^{1 *}$, Maria M. Escribese ${ }^{2}$, María Garrido-Arandia ${ }^{1}$, David Obeso ${ }^{3}$, Elena Izquierdo-Alvarez ${ }^{2}$, Jaime Tome-Amat ${ }^{1}$ and Domingo Barber ${ }^{2 *}$}

${ }^{1}$ Centro de Biotecnología y Genómica de Plantas (CBGP), Universidad Politécnica de Madrid (UPM), Instituto Nacional de Investigación y Tecnología Agraria y Alimentaria (INIA), Madrid, Spain, ${ }^{2}$ Basic Medical Sciences Department, Facultad de Medicina, Instituto de Medicina Molecular Aplicada (IMMA), Universidad San Pablo CEU, CEU Universities, Madrid, Spain, ${ }^{3}$ Centro de Excelencia en Metabolómica y Bioanálisis (CEMBIO), Facultad de Farmacia, Universidad San Pablo CEU, CEU Universities, Madrid, Spain

Allergy is defined as a complex chronic inflammatory condition in which genetic and environmental factors are implicated. Sphingolipids are involved in multiple biological functions, from cell membrane components to critical signaling molecules. To date, sphingolipids have been studied in different human pathologies such as neurological disorders, cancer, autoimmunity, and infections. Sphingolipid metabolites, in particular, ceramide and sphingosine-1-phosphate (S1P), regulate a diverse range of cellular processes that are important in immunity and inflammation. Moreover, variations in the sphingolipid concentrations have been strongly associated with allergic diseases. This review will focus on the role of sphingolipids in the development of allergic sensitization and allergic inflammation through the activation of immune cells resident in tissues, as well as their role in barrier remodeling and anaphylaxis. The knowledge gained in this emerging field will help to develop new therapeutic options for allergic disorders.

Keywords: sphingolipid, inflammation, allergy, sphigosine-1-P, ceramide-1-P, disruption epithelial barrier

\section{INTRODUCTION}

Araceli Díaz-Perales

Araceli.diaz@upm.es

Domingo Barber

domingo.barberhernandez@ceu.es

Specialty section:

This article was submitted to

Allergens,

a section of the journa

Frontiers in Allergy

Received: 03 March 2021

Accepted: 10 May 2021

Published: 14 June 2021

Citation:

Díaz-Perales A, Escribese MM

Garrido-Arandia $M$, Obeso $D$

Izquierdo-Alvarez E, Tome-Amat $J$ and

Barber D (2021) The Role of

Sphingolipids in Allergic Disorders.

Front. Allergy 2:675557.

doi: 10.3389/falgy.2021.675557
Allergic disorders, including asthma, atopic dermatitis (AD), and food allergy (FA), entail significant morbidity worldwide. These pathologies are type 2 (T2) immunological diseases that result from complex mechanisms that include aspects such as genetic background, epigenetic background, and environmental influences (1). They show distinctively diverse clinical manifestations, suggesting the presence of additional unique pathogenic processes involved in shaping their heterogeneous phenotypic attributes (2).

The prevalence of allergic diseases is around $25 \%$ of the population of the world, with an increasing trend, regardless of age, gender, or ethnicity. The treatment of these diseases is based on the identification of their sources (allergens) and their avoidance, which is not always possible (2). Allergic patients with cross-reactivity, sensitization to multiple allergens, require in most cases prophylactic and symptomatic treatments. Current treatments are often suboptimal, resulting in a reduced quality of life for the patients and placing an economic burden on society. A deeper understanding of their pathogenic mechanisms might lead to much needed and improved disease

Recently, it has been proposed that sphingolipids and the enzymes involved in their metabolism may play a role in the development of allergic diseases $(4,5)$. Sphingolipids are key factors in cell growth, survival, inflammation, and tissue remodeling (4-8). Among them, sphingosine-1phosphate (S1P) is of particular interest due to its pro-inflammatory effects $(4,5)$; however, other sphingolipids such as ceramide (CER) have the opposite effect. Therefore, the balance between biomarkers (3). 
sphingolipid synthesis and degradation is crucial for the regulation of inflammation and tissue remodeling $(4,5)$.

In this review, we summarize the biochemistry of sphingolipids, as well as their immunological importance and their role in the pathogenesis of allergic disorders.

\section{SPHINGOLIPIDS}

Sphingolipids and their intermediates are an extraordinarily diverse group of molecules with a vast array of physical properties, which are present in almost all eukaryotic organisms (9). Their basic structure is composed of a sphingoid base backbone attached by an amide bond to different fatty acids or a head group at the primary hydroxyl (3). The nature of the head group is highly variable, and it defines the different sphingolipid species: CER, in which the head group is substituted by hydrogen; sphingomyelins, in which the head group is substituted by phosphocholine; and cerebrosides or gangliosides, in which hundreds of different monosaccharides in a single or combined form make the compound $(10,11)$.

The simplest member, CER, is often referred to as the core of sphingolipid metabolism because of its fundamental role in the accumulation of de novo sphingolipids as well as in serving as a precursor for derived molecules. The biosynthesis of these lipids involves multiple enzymatic processes for the conversion to different species, where each enzyme serves as a control point for maintaining homeostasis (12) (Figure 1).

From a biological point of view, sphingolipids are found mainly in the plasma membrane, the lumen of intracellular organelles, and lipoproteins, where they act as a reservoir of bioactive metabolites for functions related to signaling, cell survival and growth, immune cell trafficking, and vascular and mucosal integrity $(8,13,14)$. Metabolites such as S1P and ceramide-1-phosphate $(\mathrm{C} 1 \mathrm{P})$ are the most common and potent bioactive mediators (15). An increase in C1P along with a decrease in S1P induces cell death pathways, while the opposite scenario results in the stimulation of anti-apoptotic pathways $(8,12,15-18) . \mathrm{C} 1 \mathrm{P}$ is related to caspase-3-mediated apoptosis and cell cycle arrest while S1P is related to proliferation and survival $(19,20)$.

\section{Sphingosine-1-Phosphate}

Sphingosine-1-phosphate is involved in the differentiation of many immune cell types, inducing changes in their functional phenotypes and taking part in the regulation of pro-inflammatory cytokines and eicosanoids. Simultaneously, specific stimuli may cause the activation of intracellular kinases to produce higher amounts of S1P. In the case of cells circulating through the vascular system, the presence of S1P in the plasma does not seem to have an effect on them per se, suggesting that the regulation of SIP receptors (S1PRs) on the membrane, rather

\footnotetext{
Abbreviations: AD, atopic dermatitis; C1P, ceramide-1-phosphate; CER, ceramide; CERK, ceramide kinase; ER, endoplasmic reticulum; FA, food allergy; ILCs, innate lymphoid cells; iNKTs, invariant natural killer T cells; MC, mast cells; $\mathrm{SPH}$, sphingosine; SphK, sphingosine kinases; S1P, sphingosine-1-phosphate; S1PRs, sphingosine-1-phosphate receptors.
}

than the presence of $\mathrm{S} 1 \mathrm{P}$, is the main factor mediating their effects $(8,16,21)$.

Maintained concentrations of S1P in plasma and tissues within a specific range are essential for barrier function. Physiologic S1P plasma concentrations $(0.5-1 \mu \mathrm{M})$ keep microvascular barrier integrity via ligation to the S1PR (22). In studies in the animal model, exogenous addition of S1P to endothelial cells increased monolayer integrity rapidly and dose-dependently through the same receptor.

In addition, S1P regulates the activation and functions of many immune cells and regulates diverse immunological processes $(14,23,24)$. For example, it acts as a chemoattracting signal for macrophages and mast cells (MCs), leading them to inflammation sites for tissue repair $(25,26)$ (Figure 2).

In the case of S1P receptors, five members of this family (S1PR1-S1PR5) have been described to bind S1P with high affinity (27) (Table 1). They belong to the Gprotein coupled family and are expressed widely but differently depending on the cell type or organ. The S1P-S1PR axis regulates the traffic and migration of most immune cell types, cytoskeleton rearrangements, cell-matrix contacts, adhesive junction assembly, and barrier integrity $(16,21)$.

S1PR1 expression was first described in the endothelium (28). This receptor is necessary for the maintenance of the vascular barrier function, and it is tightly related to its permeability. It is also expressed in immune cells such as macrophages, neutrophils, eosinophils, dendritic cells, and lymphocytes, where it plays a role in migration, through an S1P gradient. Furthermore, it is related to the activation of PI3K and PKC pathways (29).

S1PR2 is also expressed in the vascular endothelium and in monocytes, macrophages, eosinophils, MCs, and lymphocytes. In macrophages, it has an antagonistic role to S1PR1, and it regulates the phagocytic capacity as well (25). Besides this, it activates the Rho/ROCK signaling pathway and has a pro-inflammatory role due to the activation of the NF- $\kappa \mathrm{B}$ transcription factor (30).

S1PR3 is expressed in different immune cells, having a role in dendritic cell maturation, macrophage chemotaxis, and reactive oxygen species production, and neutrophil and eosinophil recruitment (25). S1PR4 antagonizes with S1PR1 in dendritic cells, regulating their ability to migrate from the periphery after antigen uptake. It also activates Rho-kinases and promotes cytoskeletal rearrangement (31). S1PR5 is mainly found in oligodendrocytes, eosinophils, and MCs. It induces the egress of immune cells in the bone marrow (25).

\section{Ceramide-1-Phosphate}

Ceramide-1-phosphate, produced in the trans-Golgi by CERkinase, activates cytosolic phospholipase-A2 $\alpha$, the enzyme that releases the eicosanoid precursor arachidonate (32), and also increases the regulation of another family of transcription factors closely related to the induction of cyclooxygenase- 2 and the subsequent production of eicosanoids (15). Moreover, C1P can mediate MCs degranulation in a $\mathrm{Ca}^{2+}$ dependent manner. Ceramide kinase (CERK) required $\mathrm{Ca}^{2}+$ for its activation, it being calmodulin the probable $\mathrm{Ca}^{2+}$ sensor (33). As degranulation involves the fusion of vesicles with the plasma 


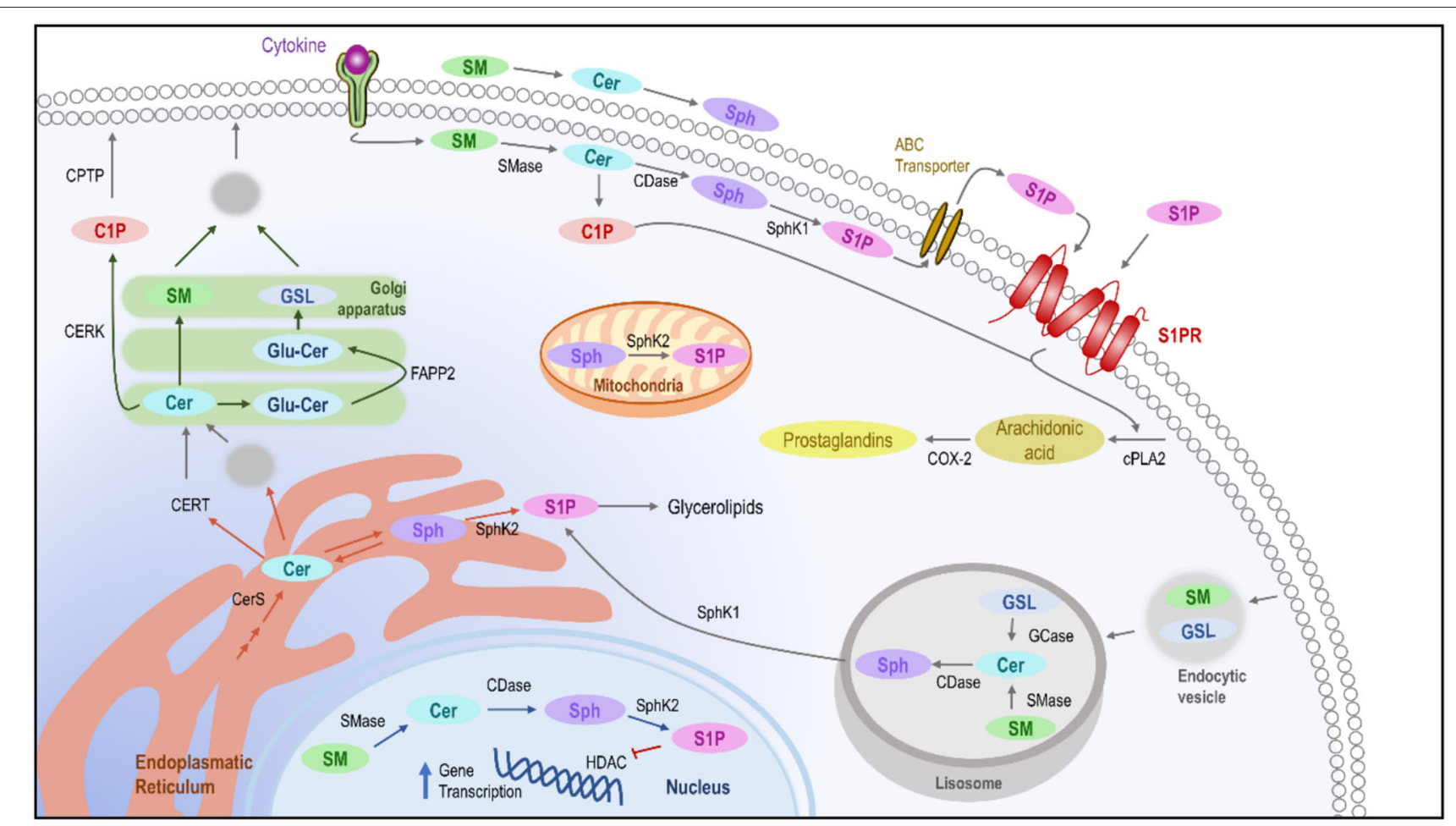

FIGURE 1 | Intracellular pathways of sphingolipids. De novo ceramide synthesis takes place in the ER where it might be delivered to the Golgi apparatus using the ceramide transfer protein by vesicular transport to synthesize sphingomyelin glucosylceramide or C1P, which will become part of the plasmatic membrane. In the membrane, after the presence of stimuli, the different enzymes implicated in the homeostasis of the sphingolipids are activated, leading to the production of $\mathrm{C} 1 \mathrm{P}$ and S1P, which in the end leads to the activation of phospholipase-A2 and the production of prostaglandins as inflammatory mediators. Moreover, the sphingolipids can also be metabolized in lysosomes, leading to the release of sphingosine and in the cellular nucleus, where S1P could block the transcription of genes related to inflammation. ER, Endoplasmic reticulum; C1P, Ceramide-1-Phosphate; CDase, Ceramidase; CER, Ceramide; CERK, Ceramide kinase; CERS, Ceramide Synthase; CERT, Ceramide transfer protein; CPTP, Ceramide-1-phosphate protein transport; GSL, Glucosylceramide; SM, Sphingomyelin; SMase, Sphingomyelinase; S1P, sphingosine-1-phosphate; SPH, Sphingosine; SphK, Sphingosine kinase.

membrane, it has been suggested that the conversion of CER to $\mathrm{C} 1 \mathrm{P}$ may alter the equilibrium of the sphingolipids in the membrane and lead to further fusion of the vesicles (33). In contrast, C1P has been shown to inhibit the TNF release $(34,35)$.

While many aspects of the $\mathrm{C} 1 \mathrm{P}$ receptor remain unknown, it has been described that the extracellular recognition of $\mathrm{C} 1 \mathrm{P}$ induces the activation of the CERK pathway, causing a mitogenic effect in macrophages (17), as it promotes cellular proliferation and growth. Inside the cells, this molecule regulates the interaction of phospholipase-A2 $\alpha$ with its inhibitors, leading to the inflammatory response mediated by arachidonic acid and prostaglandins (36).

\section{SPHINGOLIPIDS AND ALLERGIC DISORDERS}

\section{Sphingolipids and Asthma}

Asthma is a heterogeneous pathology influenced by both environmental and genetic factors. It is clinically defined as a chronic lung disease associated with narrowing of the airways, bronchial hyperactivity, and increased mucus production. Sphingolipids are the major components of lung surfactants, and they are essential for the maintenance of epithelial barrier integrity (37).

Sphingolipid metabolites, especially S1P, contribute to the pathogenesis of asthma. In the middle of the last century, it was described that the secretions of patients with respiratory diseases, such as cystic fibrosis or viral infections, showed higher lipid content compared to controls (38). In the same way, levels of S1P were higher in the lungs of patients with allergic asthma (39); significantly, in bronchoalveolar lavage fluid (BALF) from asthmatic patients after allergen challenge (40).

Experimental models of allergic asthma have demonstrated that S1P plays a crucial role in the development of the asthmatic phenotype $(39,41)$. Subcutaneous injections of S1P resulted in the progressive development of airway inflammation and air hyperreactivity response (AHR), which reached their maximum 2 weeks after the last dose (39). Moreover, local application of exogenous S1P in a murine model aggravated the allergen-induced airway inflammation, resulting in an increased contraction of the bronchi and increased airway resistance, as well as MC and eosinophil recruitment in the lung $(41,42)$.

On the contrary, inhibition of sphingosine kinase (SphK) 1, which is crucial for the synthesis of S1P, resulted in attenuated 


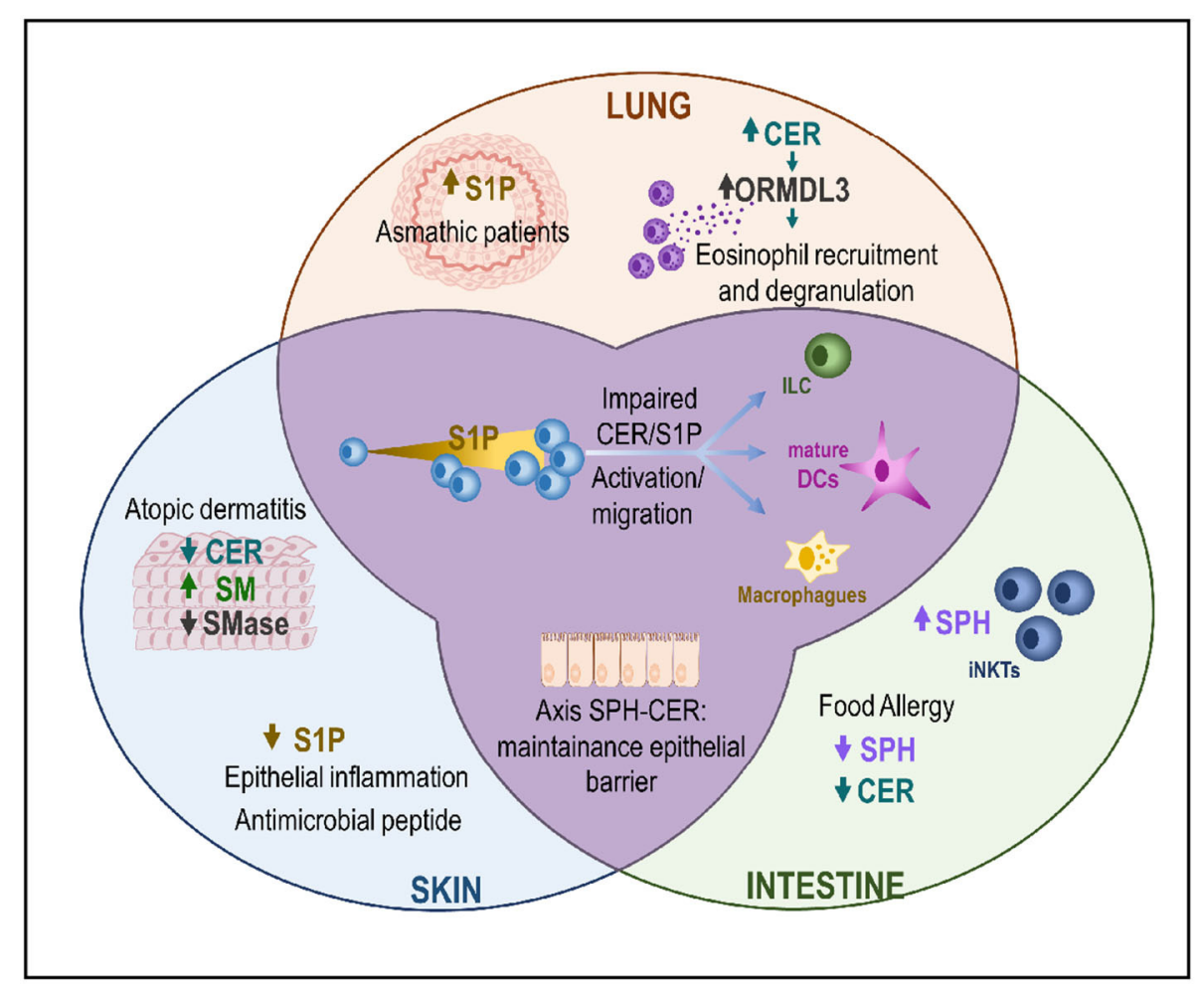

FIGURE 2 | The CER/S1P axis in the MALT. Changes in the CER/S1P ratio triggers activation and migration pathways in ILCs, dendritic cells, and macrophages. This axis plays a role in different compartments of the MALT (skin, lung, and/or intestine) with different organ-dependent results. In the skin, downregulation of CER and SM causes increased permeability, which is associated with a higher penetration of bacteria and/or allergens, which in turn will increase inflammation. In the lung, asthmatic patients show higher levels of S1P. This disease is tightly related to increased ORMDL3 expression, with a concomitant increase in the CER levels and eosinophilia. Finally, in the intestines, decreased levels of sphingolipids and S1P are associated with the development of FA in patients. CER, Ceramide; DC, Dendritic cells; ILC, Innate lymphoid cells; iNKTs, invariant natural killer T cells; SM, Sphingomyelin; SMase, Sphingomyelinase; S1P, sphingosine-1-phosphate; SPH,

Sphingosine; ORMDL3, Orosomucoid-like 3; FA, Food allergy.

airway inflammation and AHR in a model of allergic asthma (43). Similarly, application of the immunosuppressant drug FTY720/fingolimod (sphingosine analog), which interferes with S1P-S1PR interaction, inhibited the airway remodeling, which followed a repeated allergen exposure in rats (44).

Ceramide synthesis also seems to be involved in asthma, based on the increased expression of Orosomucoid-like 3 (ORMDL3), an endoplasmic reticulum (ER)-resident transmembrane protein that regulates the activity of serine palmitoyltransferase (SPT) (45). It has also been suggested to be involved in ER-mediated calcium signaling and stress response in immune cells (46); as well as in eosinophil trafficking, recruitment, and degranulation in murine models of allergic asthma (47).

This protein acts as a negative regulator of sphingolipid biosynthesis. Its overexpression in the respiratory tract of asthmatic patients promotes CER synthesis and the development of T2 responses in the airways $(45,48)$. The nasal administration of FTY720/fingolimod reduced ORMDL3 expression and CER levels, mitigating the airway inflammation and mucus hypersecretion in house dust mite-challenged mice (49).

Polymorphisms at ORMDL3 locus have been associated with increased risk for asthma (50-52), severe asthma (53, 54), and early viral respiratory infections (55), and it is a wellknown risk factor for persistent wheezing and a risk factor for asthma development $(55,56)$. In this way, variants at the 17 q21 locus have been shown to enhance the association between early respiratory infections and childhood asthma $(55,56)$. In particular, infections with human rhinovirus (HRV), the most common trigger for asthma exacerbations (57), are associated with a more than 10 -fold increased odds ratio for childhood asthma in children who carry the asthma-associated ORMDL3 genotype (56).

In mouse lungs, ORMDL3 expression can be increased by a variety of stimuli, such as allergens, tobacco smoke, and lipopolysaccharides (58). Although ORMDL3 polymorphisms have not been associated with atopy $(51,59,60)$, some seem related to $\mathrm{T}$ helper cell type 2 (Th2) cytokine responses (61) and asthmatic responses to allergens (62). Overexpression of human ORMDL3 in transgenic mice showed an associated increase in airway remodeling (smooth muscle, fibrosis, mucous production) and an enhanced IgE response compared to wild-type mice following allergen challenge (58). It has been demonstrated that there are differences in DNA methylation at the ORMDL3 gene between asthmatics and controls (63). 


\section{Sphingolipid and Atopic Dermatitis}

Mammalian skin contains extensive amounts of lipids, mainly in the epidermis, where ceramides, cholesterol, and free fatty acids can be found. Keratinocytes produce sphingolipids de novo from palmitoyl-CoA and serine in the form of glucocerebrosides and sphingomyelin. These are secreted into the stratum corneum, the outer layers of the skin, where they are transformed into ceramides for the skin barrier (64). Skin lipids, directly or indirectly, are key components in maintaining the barrier homeostasis, and any defects in the metabolism of skin lipids are related to skin barrier dysfunction (65-67).

Epidermal barrier dysfunction has been observed in both areas with $\mathrm{AD}$ lesions and areas without such lesions, in the shape of increased trans-epidermal water loss, raised skin $\mathrm{pH}$, altered surface microbiota colonization pattern, and an affected ceramide profile. The underlying attenuated barrier function in $\mathrm{AD}$ results in the continuous generation of cytokines and chemokines, a pro-inflammatory cytokine cascade, and intrusions of allergens and antigens, which contribute to the “atopic march" (68).

The alteration of CER composition in the epidermis not only contributes to an impaired skin barrier but also promotes the development of inflammatory and allergic properties in individuals with $\operatorname{AD}(69,70)$. The content of ceramides is significantly lower in patients with $\mathrm{AD}$ with $\mathrm{FA}$ than in those without (71) FA. Over the past years, several studies have reported an increase in the expression of sphingomyelin deacylase and a reduction in the expression of sphingomyelinase (SMase) in $\mathrm{AD}$, which may cause a decrease in total ceramides (72). In relation to this, mice lacking the enzyme ceramide synthase 4 (CERS4) present a disrupted epidermis and a CD45infiltrated dermis, even without the topical application of an allergen or irritant (73). In contrast, high levels of CERS4 in AD contribute to the enhanced synthesis of short-chain ceramides (74), constructing a healthier skin, more resistant to aggressions.

Another role of the sphingolipids in the skin is related to bacterial homeostasis. In this context, an increase in S1P lyase

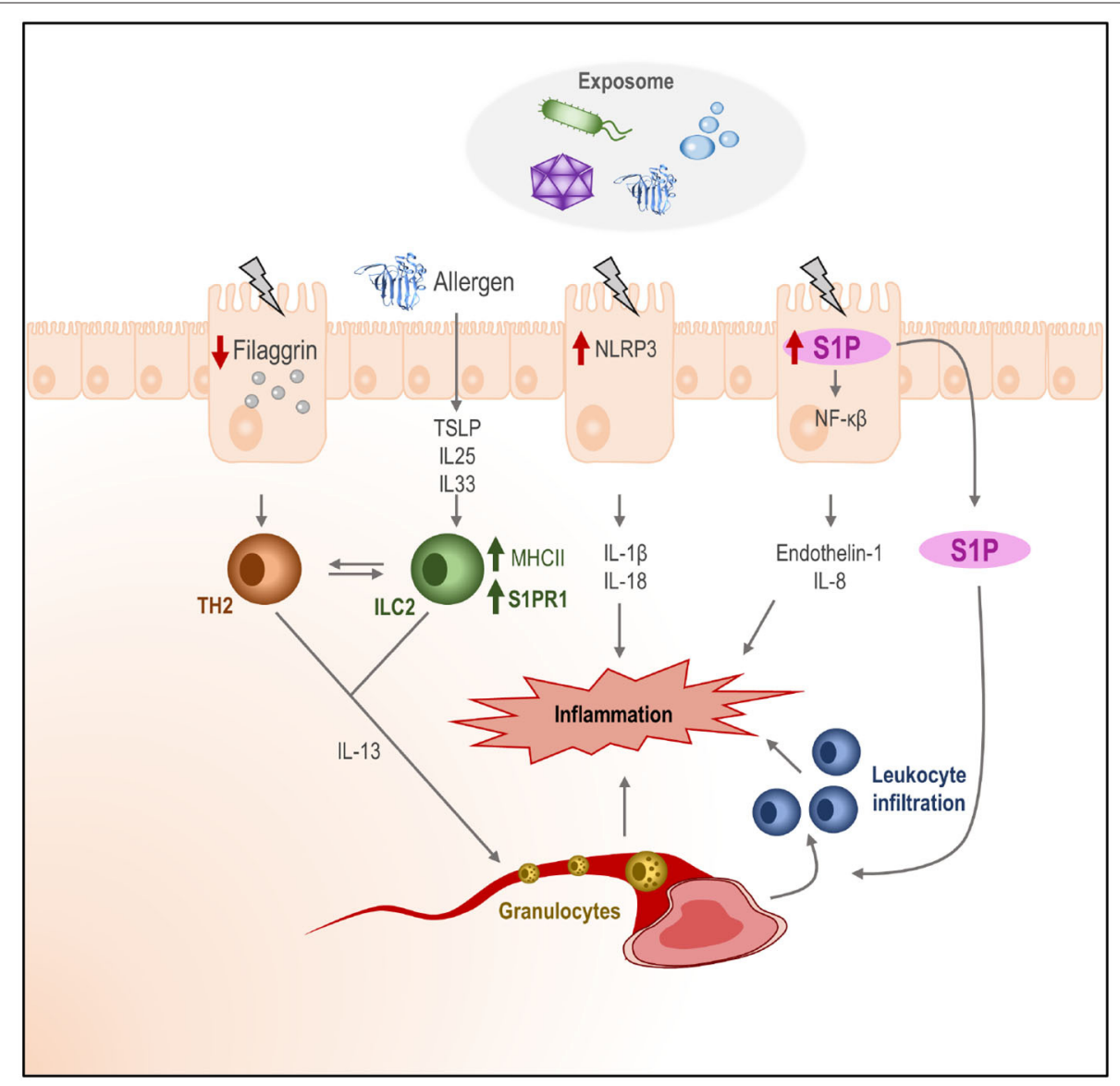

FIGURE 3 | Effect of the exposome in human tissues and role of the S1P. The exposome (bacteria, allergens, chemicals, etc.) may cause damage in the outer layers of the skin. Keratinocytes may activate (depending on the nature of the signal) different intracellular routes for the activation of the inflammasome (NLRP3), the production of S1P, and the downregulation of filaggrin production, which would increase skin permeability. Additionally, alarmins (IL25, IL33, and TSLP) and pro-inflammatory cytokines (IL $1 \mathrm{~b}$ and IL18) would be produced by keratinocytes, initiating an immune activation state in the dermis, where ILC2 would be activated and their receptor pattern would change. The release of S1P to the dermis may increase leukocyte infiltration. The homed cells activated ILC2, and leukocytes in the cytokine context on the dermis would create an inflammatory state in the skin. 
activity ends in a reduction of S1P concentrations $(64,75)$. Since S1P upregulates cathelicidin, an antimicrobial peptide produced by keratinocytes, its reduction also compromises the first immune response (76). This alteration results in the growth of special microflora of the skin, like Pseudomonas aeruginosa and Staphylococcus aureus, both of which relate to AD severity (77). The defense system of the skin against bacterial invasion is significantly disrupted in patients with $\mathrm{AD}$. Interestingly, $\mathrm{T} 2$ cytokines, interferon (IFN) $-\gamma$, and tumor necrosis factor (TNF)$\alpha$ perpetuate the vicious cycle between the epidermal barrier dysfunction and $\mathrm{AD}$ pathogenesis (78).

Finally, not only AD but allergic contact dermatitis is also affected by S1P. In a murine contact dermatitis model, the topical application of S1P reduced the weight and the cell number in regional lymph nodes (79). The number of dendritic cells migrating from the skin to the lymph node was reduced, and the cytokine pattern in the regional lymph nodes was affected by the topical treatment with S1P (80).

\section{Sphingolipids and Food Allergy}

Food allergy has been characterized by a marked decrease in levels of sphingolipids, including sphingomyelins and ceramides, in plasma (81). These changes observed in patients with FA suggest a low ceramide production and attenuation of additional distal steps in the conversion of ceramides into sphingomyelins, possibly at the level of the enzymes sphingomyelin synthase and SMase.

Regarding sphingolipids and protein interactions (i.e., protein carriers), many aspects are still unknown. However, results carried out by incubating peripheral blood mononuclear cells with these sphingolipids suggest that their presence is essential to induce the activation of invariant Natural killer $\mathrm{T}$ cells (iNKT) cells, thereby promoting the production of T2 cytokines and facilitating IgE mediated sensitization (82-84). iNKTs can recognize lipid ligands presented by the atypical MHC class I molecule CD1d, including human sphingolipids, as well as Bacteroides, plants, and animals. The role of this cell type in the pathogenesis of FA, in particular, and in allergic disorders, in general, remains unknown. Children alleric to cow's milk show a decrease in the number of iNKT cells in the blood, while an increase has been reported after milk desensitization (85).

In the intestine, sphingolipids can be found in large quantities, not only from de novo synthesis but mostly because of their abundance in food such as meat, milk, and eggs (86). Sphingolipids from food intake are metabolized to CER and

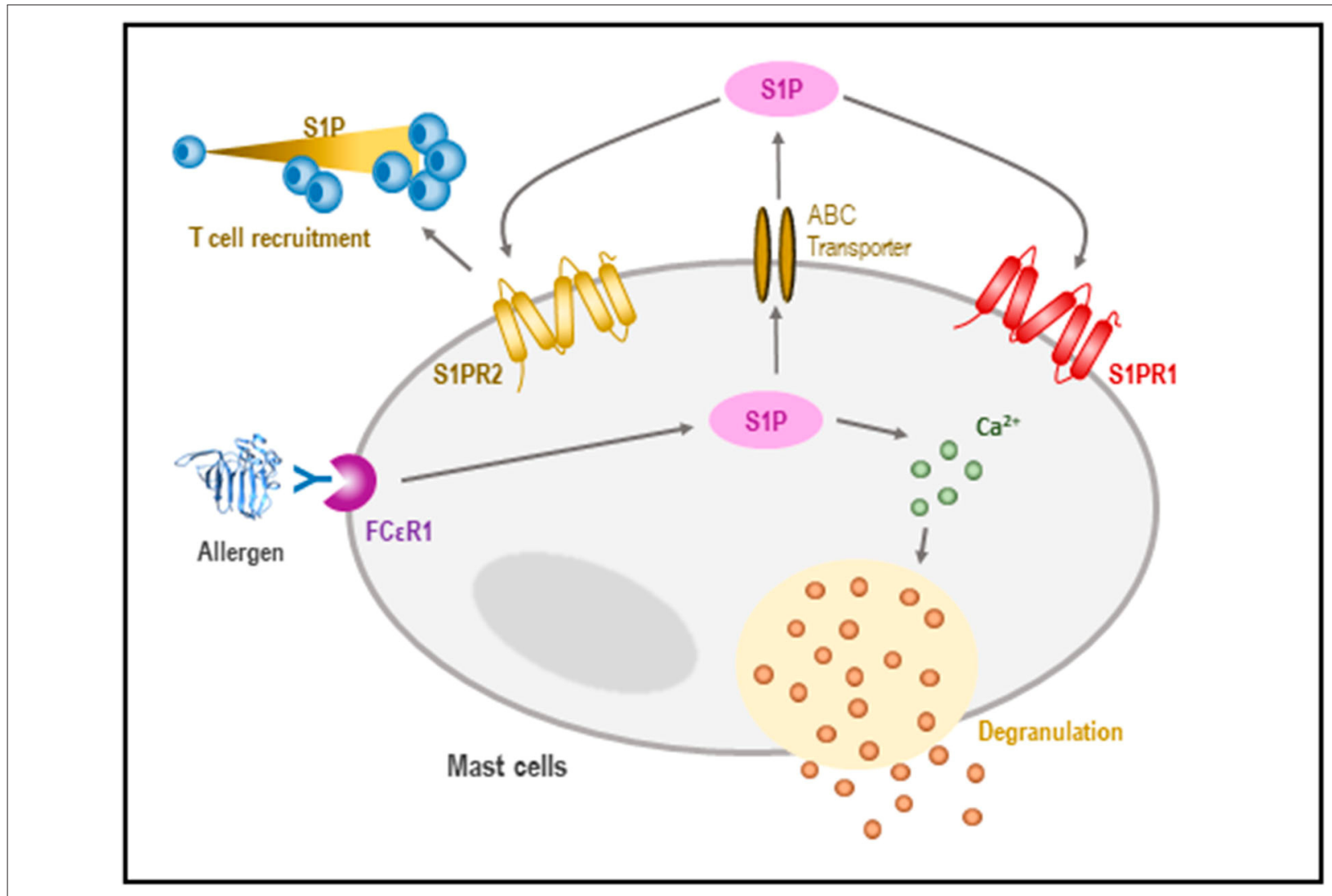

FIGURE 4 | Role of S1P in the regulation of mast cells (MCs). In response to an antigen, the activation of SphK takes place, leading to the formation of S1P. S1P may influence calcium homeostasis, allowing MC degranulation. Likewise, S1P can be released outside the cell, where it is recognized by sphingosine receptors which promote both chemotaxis and T-cell recruitment. 
sphingosine (SPH) by the intestinal epithelial cells (86). An excess of sphingolipids in the diet is associated with an increased population of plasma cells producing IgA antibodies in the colon, as well as the development of FA by the expansion and recruitment (87) of intestinal macrophages.

Plants are another source of sphingolipid. Some studies suggest that they constitute up to $10 \%$ of plant lipids (88). Curiously, over $50 \%$ of all plant allergens are lipid carriers (89), and these ligands may act as adjuvants and tilt the immune system toward a T2 (pro-allergenic) response (82). In the case of allergenic Lipid Transfer Proteins from plants (nsLTPs), their natural ligand is a sphingolipid derivative $(83,84,90)$. Recent evidence suggests that this ligand could be a functional analog of human SPH since it interacts with SphK with the concomitant phosphorylation, which could mimic the function of S1P in human inflammatory responses (91).

On the other hand, the skin also may play an important role in FA sensitization. The skin has been classically described as a tolerogenic tissue, given the predisposition of epidermal Langerhans cells to produce IL10 upon stimulation, as well as their inability to translocate NFผB-related transcription factor RelB to the nucleus $(92,93)$. However, there is growing evidence that environmental stressors can reverse this tolerogenic environment and elicit $\mathrm{T} 2$ responses to promote FA sensitization (94). The clearest evidence is the relationship between $\mathrm{AD}$ and FA: more than $80 \%$ of patients with FA have or have had AD (95). On the other hand, systemization of immune reactions initiated locally in the skin has been reported not only in FA but also in defense responses against $S$. aureus, proving that epicutaneous exposure to pathogenic bacteria ameliorates the symptomatology of secondary infections in the lung through an IgE- and mastocyte-mediated mechanism (96).

The mechanism by which the damage response in the skin can be dispersed throughout the body remains to be detailed. However, it seems increasingly clear that there is a role for invariant lymphoid cells (ILC) 2 in sensitization spreading, favoring the appearance of symptoms at other sites in the mucosa, such as the gastrointestinal tract. ILCs are immune cells of lymphoid origin that functionally resemble $\mathrm{T}$ cells but lack specific antigen receptors. They quickly respond to alterations of tissue homeostasis producing multiple cytokines that are important for the induction and regulation of inflammation. They are found in both lymphoid and non-lymphoid tissues, being particularly abundant on the mucosal surfaces of the intestine, lung, and skin, while they are infrequently detected in peripheral blood $(97,98)$.

Invariant lymphoid cells 2 could be acting as linkers between the events happening in the skin and the responses carried out in distant MALT regions. Allergic patients tend to present higher levels of this cell type in their circulation, which supports this hypothesis, and it is in accordance with previous reports of peripheral ILC2s growing in number after intranasal challenge and during the pollinic season in patients with a cat and Phleum pratense allergy, respectively $(99,100)$. An increase in the number of ILC2s has been observed in diverse allergic diseases including $\mathrm{FA}$, allergic rhinitis, asthma, and AD. Interestingly, ILCs express

TABLE 1 | An overview of sphingosine-1-phosphate (S1P) receptors.

\begin{tabular}{|c|c|c|c|c|}
\hline Receptor & Tissue & Immune cell type & Function & Location \\
\hline S1PR1 & $\begin{array}{l}\text { Endothelial cells } \\
\text { Muscle cells } \\
\text { Fibroblasts } \\
\text { Melanocytes }\end{array}$ & $\begin{array}{l}\text { Macrophages } \\
\text { Neutrophils } \\
\text { Eosinophils } \\
\text { Dendritic cells } \\
\text { Lymphocytes }\end{array}$ & $\begin{array}{l}\text { Maintenance of vascular barrier function } \\
\text { Cell migration through a S1P gradient } \\
\text { Inhibits angiogenesis } \\
\text { Required for normal embryonic heart } \\
\text { development and normal } \\
\text { cardiac morphogenesis. }\end{array}$ & $\begin{array}{l}\text { Endosome } \\
\text { Plasma membrane }\end{array}$ \\
\hline S1PR2 & $\begin{array}{l}\text { Mainly in vascular } \\
\text { endothelium } \\
\text { Low tissue specificity }\end{array}$ & $\begin{array}{l}\text { Monocytes } \\
\text { Macrophages } \\
\text { Basophil } \\
\text { Eosinophils } \\
\text { Mast cells } \\
\text { Lymphocytes }\end{array}$ & $\begin{array}{l}\text { Antagonistic role with S1PR1 in macrophages, } \\
\text { repulsing them from S1P. } \\
\text { Regulates macrophages phagocytic capacity } \\
\text { Cell proliferation } \\
\text { Suppression of apoptosis }\end{array}$ & Plasma membrane \\
\hline S1PR3 & Low tissue specificity & $\begin{array}{l}\text { Different immune cells } \\
\text { Cell } \\
\text { enriched: monocytes }\end{array}$ & $\begin{array}{l}\text { Dendritic cell maturation } \\
\text { Macrophage chemotaxis and reactive oxygen } \\
\text { species production } \\
\text { Neutrophil and eosinophil recruitment } \\
\text { Contributes to the regulation of angiogenesis } \\
\text { and vascular endothelial cell function }\end{array}$ & Plasma membrane \\
\hline S1PR4 & $\begin{array}{l}\text { Blood } \\
\text { Bone marrow } \\
\text { Lymphoid tissue }\end{array}$ & $\begin{array}{l}\text { Dendritic cells, } \\
\text { T cells } \\
\text { B cells } \\
\text { Granulocytes }\end{array}$ & Regulates the ability of dendritic cells to migrate & $\begin{array}{l}\text { Membrane } \\
\text { Mitochondria }\end{array}$ \\
\hline S1PR5 & $\begin{array}{l}\text { Blood } \\
\text { Brain } \\
\text { Skin }\end{array}$ & $\begin{array}{l}\text { Oligodendrocytes } \\
\text { Eosinophils } \\
\text { Mast cells } \\
\text { NK cells } \\
\text { T cells }\end{array}$ & $\begin{array}{l}\text { Induces the egress of immune cells in the bone } \\
\text { marrow }\end{array}$ & $\begin{array}{l}\text { Intracellular } \\
\text { Membrane }\end{array}$ \\
\hline
\end{tabular}


S1PR1, which regulates their egress from tissues to the blood, which could explain the higher number of ILCs found in inflammatory allergic conditions. As a proof of concept, patients treated with the S1PR1 agonist fingolimod (FTY720) show decreased numbers of circulating ILCs and less inflammatory ILC2s in the lungs (101).

Several studies have also confirmed the association of ILC2s with allergic asthma (102), a pathology where a CER/S1P imbalance has been related to uncontrolled inflammatory phenotypes (103). Increase ILC2s are also found in skin lesions from patients with $\mathrm{AD}$, where the composition of ceramides is altered (104).

Therefore, the local response of the skin to an insult (due to any component of the environment or an exposome) would result in an increased permeability and the production of proinflammatory (IL1b, IL18) cytokine-like proteins (TSLP, IL25, and IL33). In the case of $\mathrm{AD}$, due to a higher skin permeability, allergic sensitization is favored. In the context of an impaired skin barrier, the allergen or antigen would be more likely to gain access to the dermis, where most of the immune cells are found. Once there, ILC2 could be activated and acquire an antigenpresenting cell profile, as well as a migratory capacity, thanks to the cytokine environment. From the skin, they would relocate to other immune niches and activate the T2 response, although the details of how this activation would occur remain unknown (Figure 3).

What seems to be increasingly clear is that FA is the result of a long process of sensitization, followed by a phase of symptoms. Emerging evidence in recent years supports that both phases do not necessarily occur in the same place in the body. Increasing evidence supports the thesis that continued damage to the skin favors allergic sensitization, which then spreads throughout the body, favoring symptoms at distal sites of sensitization, such as the gastrointestinal tract.

\section{Sphingolipids and Anaphylaxis}

Anaphylaxis is an acute life-threatening multisystem syndrome resulting from the sudden release of different cell mediators in the bloodstream (105). Among the cell types that contribute most to this condition are MCs, tissue-resident effectors that respond to diverse stimuli by releasing a wide variety of mediators such as histamine. The effects of these mediators range from local to systemic inflammation. One of the most well-known stimuli received by MCs is via the FceRI (an IgE receptor), which activates the SphKs to produce S1P, which, in turn, induces MC degranulation.

Sphingosine-1-phosphate production by MCs contributes to the T2 response, which is key in the establishment of allergic inflammation. Evidence suggests that S1P has a direct effect on MCs acting in an autocrine manner via S1PR1 and S1PR2 (106). The binding of S1P to S1PR1 is translated into cytoskeletal rearrangements, regulating the migration of MCs toward antigens, while the activation of S1PR2 triggers MC degranulation $(107,108)$ (Figure 4).

In a model of systemic anaphylaxis, rapid depletion of plasma S1P to lower than $20 \%$ of basal levels was observed, contributing to cardiovascular shock during systemic inflammation. This suggests that $\mathrm{S} 1 \mathrm{P}$ may be a potential diagnostic molecule in human disease (109).

Anaphylaxis is intimately related to endothelial disruption. In relation to the endothelial barrier, the junctions in the interendothelial cleft are covered by a layer of the fibrous matrix [the endothelial surface glycocalyx, which supports the maintenance of the vascular barrier and restricts the adhesion of leukocytes and platelets to the surface of endothelial cells (110)].

Sphingosine-1-phosphate-mediated stabilization of the endothelial surface can be achieved by reducing the action of matrix metalloproteinases, which degrade this layer. Similarly, in endothelial cells, Racl activation also regulates the intracellular localization of cortactin, where the actin-binding protein interacts with myosin light chain kinase to regulate actin dynamics during the S1P- and ATP-induced endothelial barrier strengthening (110). Moreover, S1P supports vascular integrity and vascular tone via S1PR1 and S1PR2; however, only the latter is crucial for survival (25).

TABLE 2 | Role of sphingolipids in allergic diseases.

\begin{tabular}{|c|c|c|c|}
\hline Disease & Markers $^{a}$ & Role/process ${ }^{a}$ & References \\
\hline Skin disease & $\begin{array}{l}\uparrow S 1 \mathrm{P}^{\mathrm{b}} \\
\downarrow \mathrm{CER} \\
\uparrow \text { Filaggrin } \\
\downarrow \mathrm{C} 1 \mathrm{P} \\
\uparrow \mathrm{iNKTS}\end{array}$ & $\begin{array}{l}\text { S1P: } \\
\text { - Keratinocyte } \\
\text { differentiation } \\
\text { - } \text { Permeability } \\
\text { ( } \downarrow \text { tight junctions) }\end{array}$ & $\begin{array}{l}\text { Danso et al. (78) } \\
\text { Janssens et al. } \\
\text { (70) } \\
\text { Japtok et al. (64) } \\
\text { Li et al. (79) } \\
\text { Peters et al. (73) } \\
\text { Peters et al. (73) } \\
\text { Reines et al. (80) }\end{array}$ \\
\hline Asthma & $\begin{array}{l}\uparrow S 1 P \text { in BALF } \\
\uparrow O R M D L 3\end{array}$ & $\begin{array}{l}\text { S1P: } \\
\text { - } \uparrow \text { Recruitment of } \\
\text { alveolar } \\
\text { macrophages ( } \downarrow \text { tight } \\
\text { junctions) } \\
\text { - } \oplus \text { Mast cells, } \\
\text { eosinophils and } \\
\text { dendritic cells } \\
\text { ORMDL3: } \\
\text { - } \otimes \text { Sphingolipids } \\
-\uparrow \text { CER }\end{array}$ & $\begin{array}{l}\text { Arana et al. (17) } \\
\text { Cantero-Recasens } \\
\text { et al. (46) } \\
\text { Ghidoni et al. (37) } \\
\text { Ha et al. (47) } \\
\text { James et al. (19) } \\
\text { Kawa et al. (42) } \\
\text { Kowal et al. (5) } \\
\text { Luthers et al. (45) } \\
\text { Miller et al. (58) } \\
\text { Ono et al. (6) } \\
\text { Roviezzo et al. (39) } \\
\text { Schauberger et al. } \\
\text { (4) } \\
\text { Yang and Uhlig (7) } \\
\text { Zhai et al. (20) }\end{array}$ \\
\hline Food allergy & $\begin{array}{l}\text { S1P } \\
\downarrow C E R\end{array}$ & $\begin{array}{l}\text { S1P: } \\
\text { - } \uparrow \text { Recruitment and } \\
\text { expansión of mast } \\
\text { cells } \\
\text { - } \oplus \text { iNKTs } \\
\text { - } \oplus \text { ILCs } \\
\text { - IgA } \\
\text { CER: } \\
\text { - } \oplus \text { Desgranulation }\end{array}$ & $\begin{array}{l}\text { Huang (111) } \\
\text { Norris and Blesso } \\
\text { (87) } \\
\text { Nilsson (112) }\end{array}$ \\
\hline
\end{tabular}

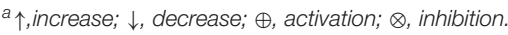

bS1P, Sphingosine-1-phosphate; CER, Ceramide; C1P, Ceramide-1-phosphate; iNKTS, Invariant natural killer $T$ cells; BALF, Bronchial alveolar liquid fluid; ILC, Innate lymphocyte cells. 
The endothelial barrier homeostasis is regulated by S1P via S1PR1 and S1PR3 through Gi $\alpha$ signaling, resulting in the induction of actin polymerization upon S1P stimulation of endothelial cells. Furthermore, the non-muscle myosin light chain kinase isoform gets phosphorylated, resulting in increased cell-cell adhesion (110).

\section{CONCLUSION AND REMARKS}

Over the past years, advances in omics have led us to change the view on lipids: from seeing them as passive components of the cell barrier to understanding them as active components and mediators of processes on cellular and tissular levels. Among these lipids, sphingolipids belong to a special family with a wide variety of effector functions: maintaining epithelial integrity, helping immune cell differentiation and migration, acting as pro-inflammatory signals, and participating in cell proliferation/apoptosis homeostasis (for summary, Table 2). The metabolism of sphingolipids and their most studied products $1 \mathrm{P}$ and $\mathrm{C} 1 \mathrm{P}$ is tightly controlled at enzymatic and binding receptor levels and their alterations contribute to the immune dysregulation that promotes the development of allergies. Sphingolipid molecules bound to allergens might thus have a relevant role in allergic sensitization. This increases the interest

\section{REFERENCES}

1. Platts-Mills TAE. The allergy epidemics: 1870-2010. J Allergy Clin Immunol. (2015) 136:3-13. doi: 10.1016/j.jaci.2015.03.048

2. Lambrecht BN, Hammad H. The immunology of the allergy epidemic and the hygiene hypothesis. Nat Immunol. (2017) 18:1076-83. doi: 10.1038/ni.3829

3. Sun WY, Bonder CS. Sphingolipids: a potential molecular approach to treat allergic inflammation. J Allergy. (2012) 2012:1-14. doi: 10.1155/2012/154174

4. Schauberger E, Peinhaupt M, Cazares T, Lindsley AW. Lipid mediators of allergic disease: pathways, treatments, and emerging therapeutic targets. Curr Allergy Asthma Rep. (2016) 16:48. doi: 10.1007/s11882-016-0628-3

5. Kowal K, Zebrowska E, Chabowski A. Altered sphingolipid metabolism is associated with asthma phenotype in house dust mite-allergic patients. Allergy Asthma Immunol Res. (2019) 11:330-42. doi: 10.4168/aair.2019.11.3.330

6. Ono JG, Kim BI, Zhao Y, Christos PJ, Tesfaigzi Y, Worgall TS, et al. Decreased sphingolipid synthesis in children with $17 \mathrm{q} 21$ asthma-risk genotypes. J Clin Invest. (2020) 130:921-6. doi: 10.1172/JCI130860

7. Yang Y, Uhlig S. The role of sphingolipids in respiratory disease. Ther Adv Respir Dis. (2011) 5:325-44. doi: 10.1177/1753465811 406772

8. Nixon GF. Sphingolipids in inflammation: pathological implications and potential therapeutic targets. Br J Pharmacol. (2009) 158:98293. doi: 10.1111/j.1476-5381.2009.00281.x

9. Iessi E, Marconi M, Manganelli V, Sorice M, Malorni W, Garofalo T, et al. Chapter five-on the role of sphingolipids in cell survival and death. In: Spetz JKE, Galluzzi L, editors. Cell Death Regulation in Health and Disease-Part A. vol. 351. Academic Press (2020). p. 149-95.

10. Merrill AH, Wang MD, Park, M, Sullards MC. (Glyco)sphingolipidology: an amazing challenge and opportunity for systems biology. Trends Biochem Sci. (2007) 32:457-68. doi: 10.1016/j.tibs.2007.09.004

11. Lopez PH, Schnaar RL. Gangliosides in cell recognition and membrane protein regulation. Curr Opin Struct Biol. (2009) 19:549-57. doi: 10.1016/j.sbi.2009.06.001 in studying them, not only to better understand the mechanisms underlying allergic diseases but also for their potential use as diagnostic and/or new prevention and treatment strategies to improve the lives of allergic patients.

\section{AUTHOR CONTRIBUTIONS}

AD-P, ME, MG-A, DO, EI-A, JT-A, and DB have made a substantial, direct and intellectual contribution to the work. AD-P and DB wrote the final version of the manuscript. All authors contributed to the article and approved the submitted version.

\section{FUNDING}

This research was funded by the Spanish Government (MINECO, grant BIO2017-84548- R); by Instituto de Salud Carlos III (ISCIII) (PI19/00044); by ISCIII co-founded by FEDER Thematic Networks and Cooperative Research Centres: ARADYAL (RD16/0006/0003; RD16/0006/0015); and by Community of Madrid (FOODAL-CM_S2018/BAAA-4574). JT-A was funded by Instituto de Salud Carlos III (ISCIII), co-founded by FEDER Thematic Networks and Cooperative Research Centres: ARADYAL (RD16/0006/0003).
12. Hannun YA, Obeid M. The ceramide-centric universe of lipid-mediated cell regulation: stress encounters of the lipid kind. J Biol Chem. (2002) 277:25847-50. doi: 10.1074/jbc.R200008200

13. Cyster JG, Schwab SR. Sphingosine-1-phosphate and lymphocyte egress from lymphoid organs. Annu Rev Immunol. (2012) 30:69-94. doi: 10.1146/annurev-immunol-020711-075011

14. Rivera J, Proia RL, Olivera A. The alliance of sphingosine-1-phosphate and its receptors in immunity. Nat Rev Immunol. (2008) 8:753763. doi: $10.1038 /$ nri2400

15. Hait NC, Maiti A. The role of sphingosine-1-phosphate and ceramide1-phosphate in inflammation and cancer. Mediators Inflamm. (2017) 2017:4806541. doi: 10.1155/2017/4806541

16. Spiegel S, Milstien S. The outs and the ins of sphingosine-1-phosphate in immunity. Nat Rev Immunol. (2011) 11:403-15. doi: 10.1038/nri2974

17. Arana L, Gangoiti P, Ouro A, Trueba M, Gómez-Muñoz A. Ceramide and ceramide 1-phosphate in health and disease. Lipids Health and Dis. (2010) 9:15. doi: 10.1186/1476-511X-9-15

18. MacEyka M, Spiegel S. Sphingolipid metabolites in inflammatory disease. Nature. (2014) 510:58-67. doi: 10.1038/nature13475

19. James BN, Oyeniran C, Sturgill JL, Newton J, Martin RK, Bieberich E, et al. Ceramide in apoptosis and oxidative stress in allergic inflammation and asthma. J Allergy Clin Immunol. (2020) 147:1936-48. doi: 10.1016/j.jaci.2020.10.024

20. Zhai C, Feng W, Shi W, Wang J, Zhang Q, Yan X, et al. Sphingosine-1phosphate promotes pulmonary artery smooth muscle cells proliferation by stimulating autophagy-mediated E-cadherin/CDH1 down-regulation. Eur J Pharmacol. (2020) 884:173302. doi: 10.1016/j.ejphar.2020.173302

21. Hla T, Dannenberg AJ. Sphingolipid signaling in metabolic disorders. Cell Metab. (2012) 16:420-34. doi: 10.1016/j.cmet.2012.06.017

22. Xiong Y, Hla T. S1P control of endothelial integrity. Curr Top Microbiol Immunol. (2014) 378:85-105. doi: 10.1007/978-3-319-05879-5_4

23. Jolly PS, Bektas M, Olivera A, Gonzalez-Espinosa C, Proia RL, Rivera J, et al. Transactivation of sphingosine-1-phosphate receptors by FceRI triggering is required for normal mast cell degranulation and chemotaxis. J Exp Med. (2004) 199:959-70. doi: 10.1084/jem.20030680 
24. Oskeritzian CA, Hait NC, Wedman P, Chumanevich A, Kolawole EM, Price MM, et al. The sphingosine-1-phosphate/sphingosine-1-phosphate receptor 2 axis regulates early airway T-cell infiltration in murine mast cell-dependent acute allergic responses. J Allergy Clin Immunol. (2015) 135:1008-18. doi: 10.1016/j.jaci.2014.10.044

25. Bryan AM, Del Poeta M. Sphingosine-1-phosphate receptors and innate immunity. Cell Microbiol. (2018) 20:e12836. doi: 10.1111/cmi.12836

26. Weigert A, Olesch C, Brüne B. Sphingosine-1-phosphate and macrophage biology-how the sphinx tames the big eater. Front Immunol. (2019) 10:1706. doi: 10.3389/fimmu.2019.01706

27. Obinata $\mathrm{H}, \mathrm{Hla} \mathrm{T}$. Sphingosine 1-phosphate and inflammation. Int Immunol. (2019) 31:617-25. doi: 10.1093/intimm/dxz037

28. Hla T, Maciag T. An abundant transcript induced in differentiating human endothelial cells encodes a polypeptide with structural similarities to G-protein-coupled receptors. J Biol Chem. (1990) 265:9308-13. doi: 10.1016/S0021-9258(19)38849-0

29. Blaho VA, Hla T. An update on the biology of sphingosine 1-phosphate receptors. J Lipid Res. (2014) 55:1596-608. doi: 10.1194/jlr.R046300

30. Zhang W, An J, Jawadi H, Siow DL, Lee JF, Zhao J, et al. Sphingosine1-phosphate receptor-2 mediated NFkB activation contributes to tumor necrosis factor- $\alpha$ induced VCAM-1 and ICAM-1 expression in endothelial cells. Prostaglandins Other Lipid Mediat. (2013) 106:62-71. doi: 10.1016/j.prostaglandins.2013.06.001

31. Sit ST, Manser E. Rho GTPases and their role in organizing the actin cytoskeleton. J Cell Sci. (2011) 124 (Pt 5):679-83. doi: 10.1242/jcs.064964

32. Pettus BJ, Bielawska A, Subramanian P, Wijesinghe DS, Maceyka M, Leslie CC, et al. Ceramide 1-phosphate is a direct activator of cytosolic phospholipase A2. J Biol Chem. (2004) 279:113206. doi: 10.1074/jbc.M309262200

33. Kim JW, Inagaki Y, Mitsutake S, Maezawa N, Katsumura S, Ryu YW, et al. Suppression of mast cell degranulation by a novel ceramide kinase inhibitor, the F-12509A olefin isomer K1. Biochim Biophys Acta Mol Cell Biol Lipids. (2005) 1738:82-90. doi: 10.1016/j.bbalip.2005.10.007

34. Tauzin L, Graf C, Sun M, Rovina P, Bouveyron N, Jaritz M, et al. Effects of ceramide-1-phosphate on cultured cells: dependence on dodecane in the vehicle. J Lipid Res. (2007) 48:66-76. doi: 10.1194/jlr.M600399-JLR200

35. Simanshu DK, Kamlekar RK, Wijesinghe DS, Zou X, Zhai X, Mishra SK, et al. Non-vesicular trafficking by a ceramide-1-phosphate transfer protein regulates eicosanoids. Nature. (2013) 500:463-7. doi: 10.1038/nature12332

36. Cifone MG, Botti D, Festuccia C, Napolitano T, Del Grosso E, Cavallo $\mathrm{G}$, et al. Involvement of phospholipase a2 activation and arachidonic acid metabolism in the cytotoxic functions of rat nk cells. Cell Immunol. (1993) 148:247-58. doi: 10.1006/cimm.1993.1109

37. Ghidoni R, Caretti A, Signorelli P. Role of sphingolipids in the pathobiology of lung inflammation. Mediators Inflamm. (2015) 2015:487508. doi: $10.1155 / 2015 / 487508$

38. Sturgill, J. L. Sphingolipids and their enigmatic role in asthma. Adv Biol Regul. (2018) 70:74-81. doi: 10.1016/j.jbior.2018.09.001

39. Roviezzo F, Sorrentino R, Bertolino A, De Gruttola L, Terlizzi M, Pinto A, et al. S1P-induced airway smooth muscle hyperresponsiveness and lung inflammation in vivo: Molecular and cellular mechanisms. Br J Pharmacol. (2015) 172:1882-93. doi: 10.1111/bph.13033

40. Ammit AJ, Hastie AT, Edsall LC, Hoffman RK, Amrani Y, Krymskaya VP, et al. Sphingosine 1-phosphate modulates human airway smooth muscle cell functions that promote inflammation and airway remodeling in asthma. FASEB J. (2001) 15:1212-4. doi: 10.1096/fj.00-0742fje

41. Chiba Y, Suzuki K, Kurihara E, Uechi M, Sakai H, Misawa M. Sphingosine1-phosphate aggravates antigen-induced airway inflammation in mice. Open Respir Med J. (2014) 4:82-5. doi: 10.2174/1874306401004010082

42. Kawa Y, Nagano T, Yoshizaki A, Dokuni R, Katsurada M, Terashita T, et al. Role of S1P/S1PR3 axis in release of CCL20 from human bronchial epithelial cells. PLoS ONE. (2018) 13:e0203211. doi: 10.1371/journal.pone. 0203211

43. Price MM, Oskeritzian CA, Falanga YT, Harikumar KB, Allegood JC, Alvarez SE, et al. A specific sphingosine kinase 1 inhibitor attenuates airway hyperresponsiveness and inflammation in a mast cell-dependent murine model of allergic asthma. J Allergy Clin Immunol. (2013) 131:50111.e1. doi: 10.1016/j.jaci.2012.07.014
44. Karmouty-Quintana H, Siddiqui S, Hassan M, Tsuchiya K, Risse PA, XicotaVila L, et al. Treatment with a sphingosine-1-phosphate analog inhibits airway remodeling following repeated allergen exposure. Am J Physiol Lung Cell Mol Physiol. (2012) 302:L736-45. doi: 10.1152/ajplung.00050.2011

45. Luthers CR, Dunn TM, Snow AL. ORMDL3 and asthma: linking sphingolipid regulation to altered T cell function. Front Immunol. (2020) 11:3120. doi: 10.3389/fimmu.2020.597945

46. Cantero-Recasens G, Fandos C, Rubio-Moscardo F, Valverde MA, Vicente $\mathrm{R}$. The asthma-associated ORMDL3 gene product regulates endoplasmic reticulum-mediated calcium signaling and cellular stress. Hum Mol Genet. (2009) 19:111-21. doi: 10.1093/hmg/ddp471

47. Ha SG, Ge XN, Bahaie NS, Kang BN, Rao A, Rao SP, et al. ORMDL3 promotes eosinophil trafficking and activation via regulation of integrins and CD48. Nat Commun. (2013) 4:1-9. doi: 10.1038/ncomms3479

48. James B, Milstien S, Spiegel S. ORMDL3 and allergic asthma: From physiology to pathology. J Allergy Clin Immunol. (2019) 144:63440. doi: 10.1016/j.jaci.2019.07.023

49. Oyeniran C, Sturgill JL, Hait NC, Huang WC, Avni D, Maceyka M, et al. Aberrant ORM (yeast)-like protein isoform 3 (ORMDL3) expression dysregulates ceramide homeostasis in cells and ceramide exacerbates allergic asthma in mice. J Allergy Clin Immunol. (2015) 136:103546.e6. doi: 10.1016/j.jaci.2015.02.031

50. Leusink M, Vijverberg SJH, Koenderman L, Raaijmakers JAM, De Jongste JC, Sterk PJ, et al. Genetic variation in uncontrolled childhood asthma despite ICS treatment. Pharmacogenomics J. (2016) 16:15863. doi: $10.1038 /$ tpj.2015.36

51. Granell R, Henderson AJ, Timpson N, St. Pourcain B, Kemp JP, Ring SM, et al. Examination of the relationship between variation at $17 \mathrm{q} 21$ and childhood wheeze phenotypes. J Allergy Clin Immunol. (2013) 131:68594. doi: $10.1016 /$ j.jaci.2012.09.021

52. Toncheva AA, Potaczek DP, Schedel M, Gersting SW, Michel S, Krajnov N, et al. Childhood asthma is associated with mutations and gene expression differences of ORMDL genes that can interact. Allergy. (2015) 70:128899. doi: $10.1111 /$ all.12652

53. Wan YI, Shrine NRG, Soler Artigas M, Wain LV, Blakey JD, Moffatt MF, et al. Genome-wide association study to identify genetic determinants of severe asthma. Thorax. (2012) 67:762-8. doi: 10.1136/thoraxinl-2011-201262

54. Binia A, Khorasani N, Bhavsar PK, Adcock I, Brightling CE, Chung KF, et al. Chromosome 17q21 SNP and severe asthma. J Hum Genet. (2011) 56:97-8. doi: 10.1038/jhg.2010.134

55. Smit LAM, Bouzigon E, Pin I, Siroux V, Monier F, Aschard H, et al. 17q21 variants modify the association between early respiratory infections and asthma. Eur Respir J. (2010) 36:57-64. doi: 10.1183/09031936.00154509

56. Çalişkan M, Bochkov YA, Kreiner-Møller E, Bønnelykke K, Stein MM, Du $\mathrm{G}$, et al. Rhinovirus wheezing illness and genetic risk of childhood-onset asthma. N Engl J Med. (2013) 368:1398-407. doi: 10.1056/NEJMoa1211592

57. Gern, J. E. How rhinovirus infections cause exacerbations of asthma. Clin Exp Allergy. (2015) 45:32-42. doi: 10.1111/cea.12428

58. Miller M, Tam AB, Mueller JL, Rosenthal P, Beppu A, Gordillo R, et al. Cutting edge: targeting epithelial ORMDL3 increases, rather than reduces, airway responsiveness and is associated with increased sphingosine-1phosphate. J Immunol. (2017) 198:3017-22. doi: 10.4049/jimmunol.1601848

59. Moffatt MF, Gut IG, Demenais F, Strachan DP, Bouzigon E, Heath $\mathrm{S}$, et al. A large-scale, consortium-based genomewide association study of asthma. N Engl J Med. (2010) 363:1211-21. doi: 10.1056/NEJMoa09 06312

60. Ober C, Yao TC. The genetics of asthma and allergic disease: a 21st century perspective. Immunol Rev. (2011) 242:1030. doi: 10.1111/j.1600-065X.2011.01029.x

61. Schedel M, Michel S, Gaertner VD, Toncheva AA, Depner M, Binia A, et al. Polymorphisms related to ORMDL3 are associated with asthma susceptibility, alterations in transcriptional regulation of ORMDL3, and changes in TH2 cytokine levels. J Allergy Clin Immunol. (2015) 136:893903.e14. doi: 10.1016/j.jaci.2015.03.014

62. Lluis A, Schedel M, Liu J, Illi S, Depner M, Von Mutius E, et al. Asthmaassociated polymorphisms in 17q21 influence cord blood ORMDL3 and GSDMA gene expression and IL-17 secretion. J Allergy Clin Immunol. (2011) 127:1587-94. e6. doi: 10.1016/j.jaci.2011.03.015 
63. Acevedo N, Reinius LE, Greco D, Gref A, Orsmark-Pietras C, Persson H, et al. Risk of childhood asthma is associated with CpG-site polymorphisms, regional DNA methylation and mRNA levels at the GSDMB/ORMDL3 locus. Hum Mol Genet. (2015) 24:875-90. doi: 10.1093/hmg/ddu479

64. Japtok L, Bäumer W, Kleuser B. Sphingosine-1-phosphate as signaling molecule in the skin: Relevance in atopic dermatitis. Allergo J Int. (2014) 23:54-9. doi: 10.1007/s40629-014-0008-2

65. Walker MT, Green JE, Ferrie RP, Queener AM, Kaplan MH, CookMills JM. Mechanism for initiation of food allergy: Dependence on skin barrier mutations and environmental allergen costimulation. J Allergy Clin Immunol. (2018) 141:1711-25. e9. doi: 10.1016/j.jaci.2018.02.003

66. Kawasaki A, Ito N, Murai H, Yasutomi M, Naiki H, Ohshima Y. Skin inflammation exacerbates food allergy symptoms in epicutaneously sensitized mice. Allergy Eur J Allergy Clin Immunol. (2018) 73:131321. doi: $10.1111 /$ all.13404

67. Tham EH, Rajakulendran M, Lee BW, Van Bever HPS. Epicutaneous sensitization to food allergens in atopic dermatitis: What do we know? Pediatr Allergy Immunol. (2020) 31:7-18. doi: 10.1111/pai.13127

68. Elias PM, Wakefield JS, Man MQ. Moisturizers versus current and nextgeneration barrier repair therapy for the management of atopic dermatitis. Skin Pharmacol Physiol. (2018) 32:1-7. doi: 10.1159/000493641

69. Yang K, Han X. Lipidomics: techniques, applications, and outcomes related to biomedical sciences. Trends Biochem Sci. (2016) 41:95469. doi: 10.1016/j.tibs.2016.08.010

70. Janssens M, Van Smeden J, Gooris GS, Bras W, Portale G, Caspers PJ, et al. Increase in short-chain ceramides correlates with an altered lipid organization and decreased barrier function in atopic eczema patients. J Lipid Res. (2012) 53:2755-66. doi: 10.1194/jlr.P030338

71. Leung DYM, Calatroni A, Zaramela LS, LeBeau PK, Dyjack N, Brar $\mathrm{K}$, et al. The nonlesional skin surface distinguishes atopic dermatitis with food allergy as a unique endotype. Sci Transl Med. (2019) 11:eaav2685. doi: 10.1126/scitranslmed.aav2685

72. Van SmedenJ, Bouwstra JA. Stratum corneum lipids: their role for the skin barrier function in healthy subjects and atopic dermatitis patients. Curr Probl Dermatol. (2016) 49:8-26. doi: 10.1159/000441540

73. Peters F, Tellkamp F, Brodesser S, Wachsmuth E, Tosetti B, Karow $\mathrm{U}$, et al. Murine epidermal ceramide synthase 4 is a key regulator of skin barrier homeostasis. J Invest Dermatol. (2020) 140:1927-37. e5. doi: 10.1016/j.jid.2020.02.006

74. Pascual JC, González I, Corona D, Hispán P, Ramos JM, Sánchez-Paya J, et al. Assessment of subclinical atherosclerosis in hidradenitis suppurativa. J Eur Acad Dermatology Venereol. (2017) 31:1229-38. doi: 10.1111/jdv.14076

75. Park K, Elias PM, Hupe M, Borkowski AW, Gallo RL, Shin KO, et al. Resveratrol stimulates sphingosine-1-phosphate signaling of cathelicidin production. J Invest Dermatol. (2013) 133:1942-9. doi: 10.1038/jid.2013.133

76. Park K, Ikushiro H, Seo HS, Shin KO, Kim, Y. Il, Kim JY, et al. ER stress stimulates production of the key antimicrobial peptide, cathelicidin, by forming a previously unidentified intracellular S1P signaling complex. Proc Natl Acad Sci USA. (2016) 113:E1334-42. doi: 10.1073/pnas.1504555113

77. Okino N, Ito M. Molecular mechanism for sphingosine-induced Pseudomonas ceramidase expression through the transcriptional regulator SphR. Sci Rep. (2016) 6:1-17. doi: 10.1038/srep38797

78. Danso MO, Van Drongelen V, Mulder A, Van Esch J, Scott H, Van Smeden J, et al. TNF- $\alpha$ and Th2 cytokines induce atopic dermatitislike features on epidermal differentiation proteins and stratum corneum lipids in human skin equivalents. J Invest Dermatol. (2014) 134:194150. doi: 10.1038/jid.2014.83

79. Li Q, Fang H, Dang E, Wang G. The role of ceramides in skin homeostasis and inflammatory skin diseases. J Dermatol Sci. (2020) 97:28. doi: 10.1016/j.jdermsci.2019.12.002

80. Reines I, Kietzmann M, Mischke R, Tschernig T, Lüth A, Kleuser B, et al. Topical application of sphingosine-1-phosphate and FTY720 attenuate allergic contact dermatitis reaction through inhibition of dendritic cell migration. J Invest Dermatol. (2009) 129:1954-62. doi: 10.1038/jid. 2008.454

81. Ois Spertini F, Switzerland L, Spertini F. Metabolomics and allergy: Opening Pandora's box. J Allergy Clin Immunol. (2020) 145:7826. doi: 10.1016/j.jaci.2020.01.012
82. Bublin $M$, Eiwegger $T$, Breiteneder $H$. Do lipids influence the allergic sensitization process? J Allergy Clin Immunol. (2014) 134:521-9. doi: 10.1016/j.jaci.2014.04.015

83. Tordesillas L, Cubells-Baeza N, Gómez-Casado C, Berin C, Esteban V, Barcik W, et al. Mechanisms underlying induction of allergic sensitization by Pru p 3. Clin Exp Allergy. (2017) 47:1398-408. doi: 10.1111/cea.12962

84. Cubells-Baeza N, Gómez-Casado C, Tordesillas L, Ramírez-Castillejo C, Garrido-Arandia M, González-Melendi P, et al. Identification of the ligand of Pru p 3, a peach LTP. Plant Mol Biol. (2017) 94:3344. doi: $10.1007 / \mathrm{s} 11103-017-0590-\mathrm{z}$

85. Lee-Sarwar K, Kelly RS, Lasky-Su J, Moody DB, Mola AR, Cheng TY, et al. Intestinal microbial-derived sphingolipids are inversely associated with childhood food allergy. J Allergy Clin Immunol. (2018) 142:33538.e9. doi: 10.1016/j.jaci.2018.04.016

86. Li Z, Kabir I, Tietelman G, Huan C, Fan J, Worgall T, et al. Sphingolipid de novo biosynthesis is essential for intestine cell survival and barrier function. Cell Death Dis. (2018) 9:173. doi: 10.1038/s41419-017-0214-1

87. Norris GH, Blesso CN. Dietary and endogenous sphingolipid metabolism in chronic inflammation. Nutrients. (2017) 9:1180. doi: 10.3390/nu9111180

88. Michaelson LV, Napier JA, Molino D, Faure JD. Plant sphingolipids: Their importance in cellular organization and adaption. Biochim Biophys Acta Mol Cell Biol Lipids. (2016) 1861(9 Pt, B):1329-35. doi: 10.1016/j.bbalip.2016.04.003

89. Goodman RE, Ebisawa M, Ferreira F, Sampson HA, van Ree R, Vieths S, et al. AllergenOnline: a peer-reviewed, curated allergen database to assess novel food proteins for potential cross-reactivity. Mol Nutr Food Res. (2016) 60:1183-98. doi: 10.1002/mnfr.201500769

90. Cuevas-Zuviría B, Garrido-Arandia M, Díaz-Perales A, Pacios LF. Energy landscapes of ligand motion inside the Tunnel-like cavity of lipid transfer proteins: the case of the Pru p 3 allergen. Int J Mol Sci. (2019) 20:1432. doi: 10.3390/ijms20061432

91. Gonzalez-Klein Z, Cuevas-Zuviria B, Wangorsch A, HernandezRamirez G, Pazos-Castro D, Romero-Sahagun A, et al. The key to the allergenicity of lipid transfer protein (LTP) ligands: a structural characterization. Biochim Biophys Acta Mol Cell Biol Lipids. (2021) 1866:158928. doi: 10.1016/j.bbalip.2021.158928

92. Igyarto BZ, Jenison MC, Dudda JC, Roers A, Müller W, Koni PA, et al. Langerhans cells suppress contact hypersensitivity responses via cognate CD4 interaction and langerhans cell-derived IL-10. J Immunol. (2009) 183:5085-93. doi: 10.4049/jimmunol.0901884

93. Shklovskaya E, O'Sullivan BJ, Ng LG, Roediger B, Thomas R, Weninger W, et al. Langerhans cells are precommitted to immune tolerance induction. Proc Natl Acad Sci USA. (2011) 108:18049-54. doi: 10.1073/pnas.1110076108

94. Angelina A, Sirvent S, Palladino C, Vereda A, Cuesta-Herranz J, Eiwegger T, et al. The lipid interaction capacity of Sin a 2 and Ara h 1, major mustard and peanut allergens of the cupin superfamily, endorses allergenicity. Allergy Eur J Allergy Clin Immunol. (2016) 71:1284-94. doi: 10.1111/all.12887

95. Dhar S, Srinivas SM. Food allergy in atopic dermatitis. Indian J Dermatol. (2016) 61:645-8. doi: 10.4103/0019-5154.193673

96. Starkl P, Watzenboeck ML, Popov LM, Zahalka S, Hladik A, Lakovits K, et al. IgE effector mechanisms, in concert with mast cells, contribute to acquired host defense against staphylococcusaureus. Immunity. (2020) 53:793-804. e9. doi: 10.1016/j.immuni.2020.11.012

97. Ebbo M, Crinier A, Vély F, Vivier E. Innate lymphoid cells: major players in inflammatory diseases. Nat Rev Immunol. (2017) 17:66578. doi: 10.1038/nri.2017.86

98. Mjösberg J, Spits H. Human innate lymphoid cells. J Allergy Clin Immunol. (2016) 138:1265-76. doi: 10.1016/j.jaci.2016.09.009

99. Doherty TA, Scott D, Walford HH, Khorram N, Lund S, Baum R, et al. Allergen challenge in allergic rhinitis rapidly induces increased peripheral blood type 2 innate lymphoid cells that express CD84. J Allergy Clin Immunol. (2014) 133:1203-5.e7. doi: 10.1016/j.jaci.2013.12.1086

100. Lao-Araya M, Steveling E, Scadding GW, Durham SR, Shamji MH. Seasonal increases in peripheral innate lymphoid type 2 cells are inhibited by subcutaneous grass pollen immunotherapy. J Allergy Clin Immunol. (2014) 134:1193-5.e4. doi: 10.1016/j.jaci.2014.07.029

101. Eken A, Yetkin MF, Vural A, Okus FZ, Erdem S, Azizoglu ZB, et al. Fingolimod alters tissue distribution and cytokine production 
of human and murine innate lymphoid cells. Front Immunol. (2019) 10:217. doi: 10.3389/fimmu.2019.00217

102. Pasha MA, Patel G, Hopp R, Yang Q. Role of innate lymphoid cells in allergic diseases. Allergy Asthma Proc. (2019) 40:13845. doi: 10.2500/aap.2019.40.4217

103. Kim SH, Jung HW, Kim M, Moon JY, Ban GY, Kim SJ, et al. Ceramide/sphingosine-1-phosphate imbalance is associated with distinct inflammatory phenotypes of uncontrolled asthma. Allergy Eur J Allergy Clin Immunol. (2020) 75:1991-2004. doi: 10.1111/all.14236

104. Morita H, Moro K, Koyasu S. Innate lymphoid cells in allergic and nonallergic inflammation. J Allergy Clin Immunol. (2016) 138:125364. doi: 10.1016/j.jaci.2016.09.011

105. Montañez MI, Mayorga C, Bogas G, Barrionuevo E, FernandezSantamaria R, Martin-Serrano A, et al. Epidemiology, mechanisms, and diagnosis of drug-induced anaphylaxis. Front Immunol. (2017) 8:614. doi: 10.3389/fimmu.2017.00614

106. Saluja R, Kumar A, Jain M, Goel SK, Jain A. Role of sphingosine-1-phosphate in mast cell functions and asthma and its regulation by non-coding RNA. Front Immunol. (2017) 8:587. doi: 10.3389/fimmu.2017.00587

107. Olivera A, Rivera J. An emerging role for the lipid mediator sphingosine-1phosphate in mast cell effector function and allergic disease. Adv Exp Med Biol. (2011) 716:123-42. doi: 10.1007/978-1-4419-9533-9_8

108. Olivera AE, Dillahunt S, Rivera J. Interrogation of sphingosine-1-phosphate receptor 2 function in vivo reveals a prominent role in the recovery from $\operatorname{IgE}$ and IgG-mediated anaphylaxis with minimal effect on its onset. Immunol Lett. (2013) 150:89-96. doi: 10.1016/j.imlet.2013.01.005
109. Gazit SL, Mariko B, Thérond P, Decouture B, Xiong Y, Couty $L$, et al. Platelet and erythrocyte sources of slp are redundant for vascular development and homeostasis, but both rendered essential after plasma S1P depletion in anaphylactic shock. Circ Res. (2016) 119:e110-26. doi: 10.1161/CIRCRESAHA.116. 308929

110. Radeva MY, Waschke J. Mind the gap: mechanisms regulating the endothelial barrier. Acta Physiologica. (2018) 222:12860. doi: 10.1111/apha.12860

111. Huang FC. The role of sphingolipids on innate immunity to intestinal Salmonella infection. Int J Mol Sci. (2017) 18:1720. doi: $10.3390 / \mathrm{ijms} 18081720$

112. Nilsson Å. Role of sphingolipids in infant gut health and immunity. J Pediatr. (2016) 173 (Suppl):S53-9. doi: 10.1016/j.jpeds.2016.02.076

Conflict of Interest: The authors declare that the research was conducted in the absence of any commercial or financial relationships that could be construed as a potential conflict of interest.

Copyright (c) 2021 Díaz-Perales, Escribese, Garrido-Arandia, Obeso, IzquierdoAlvarez, Tome-Amat and Barber. This is an open-access article distributed under the terms of the Creative Commons Attribution License (CC BY). The use, distribution or reproduction in other forums is permitted, provided the original author(s) and the copyright owner(s) are credited and that the original publication in this journal is cited, in accordance with accepted academic practice. No use, distribution or reproduction is permitted which does not comply with these terms. 